\title{
The voicelessness of theology and religious studies in contemporary Africa: Who is to blame and what has to be done? Setting a new agenda
}

\section{James N. Amanze ${ }^{1}$}

\begin{abstract}
This paper examines the voicelessness of theology and religious studies in post-independence Africa. It investigates the possible factors that have led to this phenomenon and explores ways and means whereby theology and religious studies can once again regain their rightful position not only in the academia, but also in society as a whole. It argues that unless theologians and religious educators make a radical U-turn to transform theology and religious studies into something meaningful and attractive, these two subjects will continue to be relegated to a second-class category of academic disciplines with disastrous consequences for theological and religious educators, as well as theological institutions.
\end{abstract}

Keywords: Voicelessness, secularisation, interdisciplinarity, globalisation, contextual, market-driven, hands-on-learning experience.

\section{Introduction}

It is a well-known fact that theology and religious studies are becoming less and less appealing to students and the general public in Africa today. They have become voiceless. While in the past they were regarded seriously, as major contributors to human knowledge and development, today they are looked down upon as of less economic value. This seems to be a result of a general perception prevalent in Africa today that theology and religious studies do not contribute directly to the socio-economic development of Africans.

This paper examines the factors that have led theology and religious studies into this unfortunate situation. It will be argued that a number of factors have caused the decline of these two disciplines. The paper will first examine the crucial role that theology and religious studies played prior to and immediately after independence in the social, political and economic development of Africans. It will then examine the factors that appear to have contributed towards the decline in the perceived academic value of these two disciplines. Finally, it will propose a new agenda that will ensure

1 Prof. James N. Amanze is a lecturer in systematic theology in the Department of Theology and Religious Studies at the University of Botswana. He can be contacted at amanzejn@mopipi.ub.bw. 
that the study of theology and religious studies continues unabated in institutions of higher learning.

\section{The secularisation thesis and the decline of theology and religious studies in Africa}

It has been noted in the introduction that theology and religious studies are losing their position in society not only among students at institutions of higher learning, but also among the general public. One of the ways of explaining this phenomenon is that Africa is becoming increasingly secular today. In order to express this view clearly, I have chosen to use the secularisation thesis as a theoretical framework. In this regard, before I discuss the general status of theology and religious studies today, it is important to examine the secularisation thesis and its applicability to this study.

It is important to begin this analysis by noting that according to the secularisation thesis, human societies are not static but go through a process of social and cultural transformation, including their religious values. This progressive transformation, which is a result of scientific knowledge, would lead human societies to a stage where religion would cease to have meaning and significance in the life of individuals. Urbanisation, industrialisation, economic prosperity and scientific advancement have been identified as major factors that ultimately lead to some form of secularisation in human societies. ${ }^{2}$

Thomas F. O'Dea and Janet O'Dea Aviad (1983:97) have noted that secularisation consists fundamentally of two related transformations in human thinking, namely the desacralisation of the attitude towards persons and things, and the rationalisation of thought. The secularisation of human societies entails the combination of these basic elements to the point at which a religious world-view is no longer the basic frame of reference for thought. At this stage, the world is no longer viewed as sacred and composed of things that can be affected by religion. David M. Wulff (1997:128), for one, has indicated that secularisation is a "process in which more and more problems of living are transferred from the domain of religion to the empirical arena of science". According to this view, in a system in which secularisation is manifest, "religion is denied any instrumental use, except its efficacy in transforming the human spirit and in providing a system of social ethics" (p. 128). Advocates of secularisation envisage a time when, once fully fledged, secularisation will enable people to reassign the energies they now use in praising, adoring, invoking, contemplating and entreating supernatural forces to other needs of a secular nature (p. 128).

Malcolm B. Hamilton (1995:166-167) has noted that in social theory the term "secularisation" has been used in a number of different ways that

2 The chief advocates of this thesis predicted that in future religion would decline and possibly disappear completely. Such scholars include Auguste Comte, Émile Durkheim, Karl Marx and Max Weber. 
convey different meanings. Firstly, it is used to refer to the decline of religion, whereby previously accepted religious symbols, doctrines and institutions lose their prestige. Secondly, it is also used to denote greater conformity with this world, in which case attention is turned away from the supernatural and towards concerns of this life and its problems. Thirdly, the term is used to mean the disengagement of society from religion, in which case religion withdraws from the public sphere, becomes a matter of private life, acquires a completely inward character and ceases to influence any aspect of social life outside of religion itself. Fourthly, the term is used to mean a process whereby religion undergoes a transposition of religious beliefs and institutions into non-religious forms. This involves the transformation of knowledge, behaviour and institutions that were once thought to be grounded in divine power into phenomena of purely human creation and responsibility. Fifthly, the term is used to mean the desacralisation of the world, whereby the world loses its sacred character and eventually human beings and the environment around them become the object of rational causal explanation in which the supernatural plays no part. Finally, secularisation has been used to mean the movement from sacred to secular, which involves the abandonment of any commitment to traditional values and practices, and the acceptance of change in which decision-making and actions are based on rational thinking.

It appears to me that though one cannot apply the various meanings of the term "secularisation" as articulated by Hamilton above to the African situation in their entirety, some aspects of the secularisation thesis are visible in Africa today. Many Africans today place a great deal of emphasis on material possessions and their spirituality is skin deep. The emphasis is on owning the latest brand of cars, building huge and expensive houses, having a big bank account, occupying powerful and prestigious positions in government and civil society and less commitment to the affairs of the Church or religious organizations. In addition to the above, many Africans today are scientifically minded and many of the decisions they make are characterised, to a certain extent, by critical thinking rather than emotional drive. All these are clear indicators that secularization is gradually taking place in Africa. It is important to point out that not everyone subscribes to the view that human societies undergo progressive transformation. A number of scholars have rejected the secularisation thesis outright. Notable among these is R.N. Bellah (1971, cited in Hamilton 1995:165), who has argued that the secularisation thesis is merely a myth that serves a religious purpose rather than a scientific one and that since religion performs important social functions it will continue to serve this purpose in human societies. The view that religion will continue to serve its social functions forever is shared by a number of other prominent scholars, chief among whom are T. Luckmann (1967; 1990), D.A. Martin (1969; 1991), R. Stark 
and W.S. Brainbridge (1985) to name a few. According to Hamilton (p. 166), some of these theorists have gone so far as to claim that religion will not lose its transcendental character, despite the rationalisation, and scientific and technological basis of modern societies.

It should be noted that although the secularisation thesis is heavily contested by a number of scholars as noted above, it appears to have a number of facets, which are central to this paper, and so cannot be wholly dismissed. It seems to me that in contemporary Africa, especially in the past three decades or so, as people have become increasingly educated and scientifically minded, their choices and decision-making have become gradually more rational, guided, largely, by science and not religion. In contemporary Africa, many people seem to have realised that the quickest and more assured way of achieving personal advancement and economic prosperity is through modern scientific knowledge and technology, which have proven to be effective in addressing peoples' economic problems in Europe and America. Consequently, theology and religious studies have found themselves pushed to the periphery of human knowledge and economic enterprise.

Of particular interest in this paper regarding the secularisation thesis is the view that work is one human activity that has been strategic in influencing the secularisation of human thought. O'Dea (1983:98) has observed that from a theological perspective, whatever their religious beliefs, their values and their social structure, all human beings are required to work if their societies are to survive according to the divine command (Gen. 3:19). This, however, cannot be achieved through the Word of God. The truth of the matter is that the society's growth and prosperity rest, in the first place, upon the application of intelligence and scientific knowledge to human efforts in order to satisfy human needs that are demanded by the environment in which people live. This seems to explain why academic disciplines that claim to equip students with skills and scientific knowledge that can help them to broaden their job opportunities have proved to be more popular and appealing to students, the general public and African governments.

\section{Theology and religious studies: then and now (1960-2011)}

This paper began by noting that theology and religious studies are experiencing a state of decline and that unless something is done to correct the situation their continued existence may be in jeopardy. This stands in sharp contrast to the popular status that these subjects enjoyed prior to and immediately after independence. It is noteworthy that during the colonial period and indeed the period immediately after independence, the bible constituted the basis of general education and acquisition of human knowledge and social advancement. Missionaries established a number of 
schools and colleges everywhere in Africa, which became centres of Western "civilisation". It was these schools that were largely responsible for the emergence of a new cadre of African leaders and intellectuals who spearheaded the movement for political independence of Africans. Mission schools produced a number of educated men and women who later became civil servants, teachers, doctors, nurses, policemen, soldiers, engineers, church leaders, plumbers, bricklayers, to name but a few. This new elite became the catalysts of socio-economic transformation in many African countries. Today, however, the situation has changed dramatically. The role that theological understanding of the world and society plays in the socio-economic development of people has been reduced in significance. Theological knowledge is no longer considered adequate for social advancement and economic prosperity; therefore, its popularity in institutions of higher learning has waned.

James Kombo (2011) has postulated that theology and religious studies experienced an upsurge in demand and popularity in Africa in the period between 1960 and 1980. It was fashionable for people to enrol in theology and religious studies at universities and theological institutions. Drawing from the Kenyan experience, which seems to be suggestive of the experience in the rest of Africa, theological discourse was highly valued. There were vibrant debates on theological matters that stimulated a great deal of critical thinking among scholars throughout Africa. Theologians and religious educators were very vocal indeed.

Two developments were significant during this period. In the first place, it was marked by the establishment and proliferation of theological colleges in many parts of Africa, which led to the blossoming of theological and religious studies. The theological voice was unmistakably loud and clear across the continent. This period was characterised by what can be termed an "African religious renaissance", during which African scholars reclaimed the dignity of the African religious heritage as part of God's creation. Scholars such as John S. Mbiti, Byang Kato, Kwesi Dickson, Desmond Tutu, Allan Boesak, Manas Buthelezi, to name a few, generated much debate in the academic sphere that resonated well with the emerging elite in independent Africa. From a literary perspective, what was even more important was that this period witnessed the publication of important theological books by African and some European scholars that generated a great deal of theological debate throughout the continent and changed the way in which people in Africa, as well as in Europe and America, perceived the African religious heritage. Their works generated a great deal of critical thinking and the impact thereof continues to the present day.

However, as Africa moved into the 1990s and entered the third millennium the situation began to change dramatically. The popularity of theology and religious studies began to decline. This period was marked by changes that 
have not favoured the study of theology and religious studies. In the first instance, many Christian theological institutions turned themselves into universities with government charters to validate their academic programmes. This has meant that theology and religious studies have found themselves competing with disciplines in the humanities, social sciences and natural sciences that appear to be more practical and market driven. As a result, there has been a drop in the enrolment of students in theological programmes for fear that it will not help them to find work in the job market. Ezra Chitando (2010:197), writing in the context of Zimbabwe, has noted that the question "what can one do with theology and religious studies?" is a recurring inquiry among students enrolled in theology and religious studies in many African institutions. As a student in the Department of Religious Studies, Classics and Philosophy, Faculty of Arts, he did not feel too proud of himself and noted that the inferiority complex associated with these disciplines runs deep among students because they feel themselves to be no match for students enrolled in subjects such as engineering, medicine and law. Secondly, this period has also witnessed a decline in the publication of theological books by African scholars, thereby limiting the dissemination of theological and religious knowledge on the continent.

The view that theology and religious studies are in decline is shared by a number of other scholars. For example, David T. Williams (1998:27-29), writing in the context of South Africa, has observed that theology as an academic discipline is indeed in recession. Indicators of this include the fact that theological conferences are poorly attended, buildings originally intended for theological purposes are now used for non-theological purposes, there is a loss of direction as to what theology should be concerned with now after the fall of apartheid, and there is a great deal of uncertainty among theologians concerning the future of theology in the new South Africa. In the same vein, H. Kwame Aaglo (2010:2) has observed that despite the significant mushrooming of biblical and theological seminaries in Africa today by churches and missionaries, their student population is dropping. The recession faced by theology and religious studies among students and the general public is compounded by the fact that these subjects are considered poor contributors to economic development by African governments. Bill Houston (n.d:4) has noted that in most African countries the governments have shown no interest in theological education.

It will be seen from the above discussion that in general theology and religious studies are facing a bleak future and their very existence seems uncertain. A number of factors have placed these two disciplines in this precarious situation. In the section that follows, I will examine the causes that have led to their decline in Africa today. 


\section{Challenges facing the study of theology and religious studies in Africa today}

The study of theology and religious studies is beset with challenges in post-independence Africa. These have caused the recession of these subjects in many institutions of higher learning as evidenced by the drop in student numbers and lack of interest among the general public and African governments. For a lack of space, I will discuss only a few of these challenges here.

\subsection{Post-independence Africa's quest for economic development through science}

It appears to me that one of the chief reasons for the decline of theology and religious studies in Africa today is the quest of African peoples to eradicate poverty and attain economic prosperity. From the perspective of the secularisation thesis, after independence, the new African elite and leadership, imbued with a zeal for fast economic growth and development, set in motion economic development plans that focused on improving the agricultural sector, transport, the mining sector, health services, and education. Many African leaders began to perceive that economic prosperity could only be achieved through science and technology, not the word of God, as was the case in the industrialised countries in Europe and America. This perception meant a paradigm shift in the search for solutions from theology to science.

There is a lively debate today concerning the link between science and technology and economic development the world over. The general view is that science and technology generate innovations that work as catalysts for socio-economic change. According to this view, continuous innovations generated by learning have been shown to be responsible not only for the increase in productivity, but also for the dynamic competitive advantages of companies, industries and nations in the unfolding of the global economy. Consequently, economic development is considered to be a result of this process. It is generally argued that the difference between developed countries in Europe and America and underdeveloped countries in Africa lies in their technological capability. Developed countries have successfully utilised science and technology to address the socio-economic problems of their countries (UNECA 1998:1).

It is important to note that because of the perceived benefits of science and technology in promoting socio-economic growth and development, African countries have exerted great efforts to promote science and technology in the education system, rather than theology and religious studies. This can be seen in the preference given to science enrolment in secondary, technical, vocational and tertiary institutions, and the national spending on science and technology education, and on research and 
development by African governments, the private sector and institutions of higher learning (UNECA 1998:3). In promoting these disciplines, it is argued that they have brought about new products and processes that have resulted in the creation and development of new industries, companies, clusters of high-technology companies, increases in gross domestic product and the creation of new jobs, leading to the eradication of poverty in Africa. Thus, generally speaking, science and technology are considered to be of critical importance for economic growth. Their contribution to economic empowerment is seen in a number of areas, including agriculture, transport and communications, energy, animal and human health, education, and the environment (UNECA 1998:8). Consequently, at present, a number of African governments and technocrats responsible for developing economic policies seem not to factor theology and religion into their planning, under the impression that they have nothing to do with economic development. They only regard them as a burden on national budgets.

\subsection{Failure to address contemporary issues}

Apart from African governments choosing to promote science and technology for the sake of economic development, rather than theology and religious studies, it seems plausible to argue that the decline of these two subjects is a result of their failure to address contemporary issues affecting the life of Africans in concrete terms. According to Chitando (2010:204), teaching theology and religious studies in the abstract without making reference to existential, contemporary issues faced by men, women and children on the African continent minimises the relevance of these disciplines. Chitando (p. 201-202) has observed that there is a general dismissal of the value of theology and religious studies in Africa because it is believed that these subjects, unlike science and technology, cannot address the challenges facing Africa today.

Theology is presented to people in the abstract, in complex theological terms that make no sense to people who are concerned with dealing with the practical and pressing problems of everyday life, namely disease, poverty, food and shelter. One of the reasons for the voicelessness of theology and religious studies is that they seem to be too abstract and concerned mainly with the afterlife rather than the here and now. As Sarah White and Romy Tiongco (1996:10) have observed, because of its nature, even to religious people, theology can seem too obscure, distant and with little to say about peoples' everyday needs. What is even worse is the fact that people with no religious beliefs consider religion irrelevant. White and Tiongco (p. 10) have further noted that because of the disconnect between religion and economic development, religious beliefs and values are, in most cases, relegated to the private sphere and are considered to have no place in the concrete world of development where the urgent need is to get things done. 


\subsection{Failure to employ hands-on learning experience}

Another reason for the decline of theology and religious instruction is attributed to a lack of imaginative methods of teaching, particularly a failure to use hands-on teaching methods. Chitando has observed that the teaching in these subjects is confined to the classroom, with no internships involved. This deprives students of acquiring hands-on experience as is the case in engineering, commerce and medicine, which require practical experience. It has been observed that practical involvement can help students to acquire knowledge concerning the day-to-day lives of ordinary men, women and children, thereby acquiring practical experience (Chitando 2010:204). Judo Poerwowidagdo (2008:62) has pointed out that one of the problems facing theology is its failure to relate to the daily experiences of the people. She writes:

[U]nlike the study of natural sciences which puts an important emphasis on the experimental testing both in the laboratory and in the field, and which highly values empirical verifications, theological education puts primary emphasis on the study of theological and biblical literature, where the library is the most important source of knowledge, second only to the professor. Theological praxis is hardly known. Students and their professors are not involved in the congregational or community life as part of their theological study and education, or as part of their teaching-learning process. ... Therefore, theological study is divorced from the ... needs of the world. Thus, it becomes remote and loses its contextual value, because it lacks the ingredient of active involvement and therefore becomes ... irrelevant.

It will be noted from the above text that a lack of hands-on learning experience does affect the way in which people view theology and religious studies. Their failure to be involved in the daily experiences of the people renders theology and religious studies aloof and isolated from the world (Puerwowidagdo 2008:62).

\subsection{Religious fundamentalism}

Finally, there is the issue of religious fundamentalism. Tharcisse Gatwa (2010:2-3) has noted that religious fundamentalism, as opposed to openness and wider interaction with society, does not bring about change. Theologians and Christian leaders coming from fundamentalist institutions do not become catalysts for transformation of our societies. Gatwa (p. 2-3) has observed that the great majority of Christians and the general public in Africa today expect theologians to engage and interact with their communities in a practical way. They need to devise strategies that can lead to social transformation that may lead to the eradication of poverty in their communities. This may require relevant curricula, relevant methodologies and relevant content. 


\section{The future of theology and religious studies: Setting a new agenda}

Having discussed some of the factors that have led to the decline of theology and religious studies, in this section of the paper I will propose a new agenda in the study of these subjects that may help to bring them to the fore once again. There is a need to set a new course regarding the way in which theology and religious studies are presented in the curriculum. As Puerwowidagdo (2008:62) has observed, it would be catastrophic if the same traditional patterns of theological education inherited from the past century continue unchanged. Theological institutions cannot afford to continue doing the same thing repeatedly. In view of the challenges faced by theology and religious studies today, the new agenda proposed below may achieve the desired results, for as Art Deyo (2000:375) has indicated "[T]oday, virtually every area of our lives is being twisted and turned by forces beyond our control. ... to stay alive in such a world, [one] needs to develop an understanding of the forces reshaping the globe ... Like the ocean tides, change drivers cannot be controlled nor can they be ignored, but they can be used."

\subsection{Theology and religious studies as catalysts of socio-economic development}

In view of the fact that we live in a world today that is becoming increasingly secular, there is a need to develop theological programmes that take into account the quest of African peoples for rapid socio-economic development. Theology must prepare people not only for the afterlife, but also for socio-economic empowerment. The view that religion plays a very important role in economic development has been noted by a number of scholars in the past, notable among whom was Max Weber (1930). Weber stressed that the Calvinist doctrine of double predestination stressed diligence, austerity, thrift, punctuality, fulfilment of promises and fidelity to group interests. These values laid the foundation for modern capitalism (Khan and Bashr 2008:2-4). There is a need therefore for a new agenda that presents theology and religious studies as catalysts of economic development like any other academic subject. There is a need to correct the erroneous perception that theology and religious studies do not contribute towards economic development of human societies. Recent scholarship has shown that these subjects play a major role in economic growth and development.

For example, Habibullah Khan and Omar Bashr (2008:3) have argued that theologians should and must make a case for theology by arguing that religion can act as a catalyst for the accumulation of social capital and thereby growth, which is a widely accepted norm in development. By "social capital" is meant the internal social and cultural coherence of 
societal norms and values that govern interactions among people, and the institutions in which they are embedded. According to Khan and Bashr (p. 2-4), social capital consists of civil social capital and government social capital. Civil social capital refers to trust, reciprocity, interpersonal cooperation and coordination that govern the interaction among economic agents. Government social capital entails the benefits of law, order, property rights, education, health and good government. It has been suggested that since social capital reduces transactions and information costs, and makes physical capital and human capital more productive, it should be considered a source of "total factor productivity".

It should be noted that, according to Khan and Bashr (p. 4), religion, which is categorised as civil social capital, contributes to the building of networks among people. Spiritual or religious capital produces ethical values that spill over to government social capital as well. Khan and Bashr (p. 4) have observed that religion affects productivity through certain personal traits such as work ethics, thrift, honesty, and openness to people. In addition to this, it reduces levels of corruption and criminal activity. Moreover, religion leads to healthier living by discouraging harmful activities such as overeating, gambling and alcohol abuse. Finally, religion promotes cooperation, which, in turn, helps an economy to be more open in terms of trade, investments and skilled migration.

\subsection{A market-driven curriculum}

Apart from proposing the need to align theology and religious studies with the quest for economic development, there is a need to introduce a curriculum that is market driven. According to Gatwa (2010:4-5), if theologians are to attain their rightful place in society, they must be able to address issues that have to do with climate change, desertification, exploitation of human beings by others, looting of the ecosystem, the impoverishment and marginalisation of the population, HIV/AIDS, and other calamities facing Africans today. This can be possible only if theologians are able to interact with society. There is a need to reformulate the curriculum of theology and religious studies so that it can meet the challenges concerning human rights, economic and political justice, and dialogue between the various sections of society (p. 4-5).

In agreement with Gatwa, Afaglo (2010:4) has argued that there is a need to develop value-oriented and market-driven curricula or programmes of study, thereby expanding the education horizon for leadership and introducing theological concepts that have contextual value for Africans without compromising the core values of Christianity. There is a need to introduce in the theological curriculum courses that have market value for as long as they retain Christian values. Such curricula are likely to increase the number of students in theological programmes. 


\subsection{Introducing hands-on learning experience}

In the new agenda, the need for practical experience should be emphasised. Hands-on learning experience has been defined as "learning by doing" (Haury and Rillero 1994). This is in accordance with the theory that if you want someone to be able to repair a car, then you need to give the person an actual car to repair. Again, if you want someone to learn how to cook, then you should put the person in a kitchen. The same applies to swimming. If you want to teach someone to swim, then you must take the person to the swimming pool. There is no way in which a person can learn how to swim in a classroom. Hands-on learning allows the student to learn through practical experience. It also enables students to be critical thinkers as they try to find a solution to a pressing problem. Using the hands-on learning method enables students to become active participants in the learning process rather than being passive learners. Internships in religious and theological education must be used in order to give students hands-on learning experience that they can apply later in their career. It can actually prepare them for employment. In order to achieve this, there is a need to create project-based programmes in which students can participate in the life of the community. Hands-on learning experience provides students with real-life contexts for learning. This means that students will be able to relate their theological or religious knowledge to practical problems facing the societies in which they live and be part of the solution to such problems (Haury and Rillero 1994). Hands-on learning experience can take place in institutions such as schools, colleges, clinics, hospitals, offices, prisons and the army.

\subsection{In touch with industry and the business world}

Concerning the new agenda, there is also a need to connect theology and religious studies with the business community. Although at face value there appears to be no relationship between religion and business life, scholars have found that actually there is. As a matter of fact, it has been found that religion can help businesses to be anchored in good business practices. In business life, religion can constitute the foundation of good business ethics. An academic programme on business ethics would contribute greatly towards equipping people with the ethical behaviour necessary in their professions of medicine, law, engineering, management and the like. It has been observed that businesspeople do have a number of moral problems that are very stressful to deal with. Globalisation means that businesspeople now deal with people of different faiths, which requires sensitive handling. A programme in world religions could help businesspeople learn how to deal with the various religious ideologies present in the business world today. It has been noted that religious conflict in a business community may put businesses in jeopardy. Thus, foundational religious information can help businesspeople to operate their businesses better than ever before (Lagace 2001). 
At the same time, it has been established that theologians need to learn and understand the complexities of the business world and its human aspects. Exposure to actual businesses can help theologians grapple with the responsibilities of management. Businesspeople are always confronted with conflicts that they need to resolve. Wilma Tan (2001:381) has noted that businesspeople make decisions and achieve tasks efficiently. Time is precious to them; they have schedules, meetings to attend, projects to carry out and deadlines to meet. Theologians can learn a great deal from the business world in terms of church management. There are some difficult decisions that have to be made in church communities. This requires responsible management like that of a businessperson in secular employment. Religious professionals can learn pragmatic problem-solving instead of sweeping problems under the carpet. This, however, does not mean that theologians should be turned into businesspeople, but that they need to acquire the management skills necessary for administering religious institutions effectively (Lagace 2001).

\subsection{Interdisciplinarity}

In the attempt to bring theology and religious studies to the fore, it is important to note the importance of interdisciplinarity in designing theological programmes. "Interdisciplinarity" has been defined as a process of combining components of two or more disciplines in the search for new knowledge. It is a process of answering a question, solving a problem, or addressing a topic that is too broad or complex to be dealt with adequately by a single discipline or profession (Seipel 2009:1). Thus theology can be combined with psychology, sociology, philosophy, finance, management, to name a few, and offered in a single programme of instruction. It has been observed that many complex or practical problems can only be understood by pulling together insights and methodologies from a variety of disciplines. It has further been noted that those who forget this simple truth run the intellectual risk of one-sided vision and the social risk of irresponsible action. One of the advantages of interdisciplinarity is that it enables students to move from specialisation to holistic thinking, bearing in mind the fact that the world is one (Nissani n.d.). This is in accordance with Gatwa's (2010:4) contention that there is a need for theology to interact with other disciplines. Theologians need to realise that other branches of knowledge can enrich their own subject. Interdisciplinarity means that theologians would benefit from cross-border knowledge in other disciplines rather than operate in isolation. It would also increase the number of students enrolling in theology and religious studies, thereby ensuring that the theological voice is loud and clear. 


\subsection{Research and publications from an African perspective}

This discussion would be incomplete without reference to the fact that the decline of theology and religious studies in Africa today is attributed to a lack of emphasis on research and publication of theological books by African scholars. John Pobee (2010:344) has noted that one of the drawbacks of theology in Africa today is the lack of African publications by Africans with African perspectives. He deplores the fact that most of the standard theological books are from the northern hemisphere. He contends that in the contemporary global village no group's identity should be left out. For that reason, African theologies must have their place around the theological table.

Chitando, in agreement with Pobee, has argued that since a problem facing the study of theology and religious studies in Africa is a limited research and publications output, there is a need for Africa to be a producer of knowledge and not just a consumer. In most cases, materials used in schools are produced outside Africa. Similarly, Afaglo (2010:5) has intimated that excellent theological research findings must be published in Christian academic journals for global consumption. Research products must be launched and directed towards solving the problems of society today.

\section{Conclusion}

In conclusion, this paper has examined the status of the study of theology and religious studies in Africa today. The secularisation thesis has been used in this paper as the basis of discussion and analysis. The status of theology and religious studies prior to and immediately after independence has been examined. It has been noted that these disciplines were very popular and constituted the basis of learning in missionary schools, out of which emerged a new African elite and a cadre of leaders who led Africa to independence. The challenges facing theology and religious studies have been examined in detail. The paper has proposed a new agenda that needs to be adopted in order to revitalise these academic disciplines in institutions of higher learning in Africa today. It has concluded by noting that failure to do so may put the future of these once-popular disciplines in jeopardy.

\section{References}

Adeyo, A. 2001. Global forces changing today's ministries, in The mission of an evangelist, edited by W.W. Conrad. Minneapolis, Minn.: World Wide Publications:375-376.

Afaglo, H.K. 2010. Challenge of financing Christian theological education in Africa. (Paper read at the 40th anniversary of Nobles Hall in Trinity Theological Seminary in Madina, Ghana, 20 November 2010). http://www.wiziq.com/tutorial/106548-Challenges-of-Financing-Christian-Theol ogical-Education-in-the-21st [accessed 21 Nov. 2012]. 
Chitando, E. 2010. Equipped and ready to serve? Transforming theology and religious studies in Africa. Missionalia 38(2), August:197-210.

Gatwa, T. 2010. The challenges of theological education in Africa: Sharing thoughts with WOCATI at its council. (St Colm's, Edinburgh, 31 May 2010) http://www.oikoumene.org/fileadmin/files/wcc-main/documents/p5/ete/The $\% 20$ Challenges $\% 20$ of $\% 20$ Theological $\% 20$ Education $\% 20$ in $\% 20$ Africa \%20-\%20Tharcisse\%20Gatwa.pdf [accessed 27 Nov. 2012].

Hamilton, M. 1995. The sociology of religion: Theoretical and comparative perspectives. London: Routledge.

Haury, D.L. and Rillero, P. 1994. Perspectives of hands-on science teaching. Questions and answers. 1. What is hands-on learning, and is it just a fad? http://www.ncrel.org/sdrs/areas/issues/content/cntareas/science/eric/eric-1.htm [accessed 21 Nov. 2012].

Houston, B. N.d. Missiological and theological perspectives on theological education in Africa-An assessment of the challenges facing evangelical theological education.

http://www.oikoumene.org/fileadmin/files/wcc-main/documents/p5/ete/MISSIO LOGICAL\%20AND\%20THEOLOGICAL\%20PERSPECTIVES\%20ON \%20EVANGELICAL\%20THEOLOGICAL\%20EDUCATION\%20IN \%20AFRICA1\%20-\%20Bill\%20Houston.pdf [accessed 21 Nov. 2012].

Luckman, T.1967. The invisible religion, New York: MacMillan.

Martin, D. A. 1969. The religious and the secular, London: Routledge.

Martin, D. A.1991. "The secularization issue: prospects and retrospects" in British Journal of Sociology, 42, pp.465-74.

Khan, H. and Bashr, O.K.M.R. 2008. Religion and development: Are they complementary? U21 global working paper series no. 006. http://www.u21global.com/PartnerAdmin/ViewContent? module=DOCUMENTLIBRARY\&oid=157451 [accessed 27 Nov. 2012].

Kombo, J. 2011. [personal communication]. 16 Nov., Nairobi.

Lagace, M. 2001. Can religion and business learn from each other? http://hbswk.hbs.edu/item/3511.html [accessed 21 Nov. 2012].

Nissani, M. N.d. Interdisciplinarity: What, where, why? http://www.is.wayne.edu/mnissani/pagepub/ispessay.htm [accessed 27 Nov. 2012].

O'Dea, T.F. and O'Dea Aviad, J. 1983. The sociology of religion. $2^{\text {nd }}$ edition. Englewood Cliffs, N.J.: Prentice Hall.

Pobee, J.S. 2010. "Stretch forth thy wings and fly": Theological education in the African context, in Handbook of theological education in world Christianity: Theological perspectives, ecumenical trends, regional surveys, edited by D. Werner et al. Oxford: Regnum:337-345.

Poerwowidagdo, J. 2008. Towards the $21^{\text {st }}$ century: Challenges and opportunities for theological education. Ministerial Formation 110, 
April:57-63.http://www.oikoumene.org/fileadmin/files/wcc-main/documents/p5/ Ministerial_formation/MF_110_April_08.pdf [accessed 21 Nov. 2012].

Seipel, M. 22 January 2009. Interdisciplinarity: An introduction. http://mseipel.sites.truman.edu/files/2012/03/Introducing-Interdisciplinarity.pdf [accessed 27 Nov. 2012].

Stark, R. and Brainbridge, W. S.1985. The future of religion, Berkeley: University of California Press.

Tan, W. 2001. Reaching business and professional women, in The mission of an evangelist, edited by W.W. Conrad. Minneapolis, Minn.: World Wide Publications:375-376.

UNECA (United Nations Economic Commission for Africa).1998. The contribution of science and technology to African development. (Paper read at the African Business Round Table annual general meeting in Abuja, Nigeria, 16-17 November 1998).

http://repository.uneca.org/bitstream/handle/10855/4089/bib-30747_I.pdf? sequence $=1$ [accessed 27 Nov. 2012].

Weber, M. 1930. The Protestant ethic and the spirit of capitalism. London: Allen \& Unwin.

White, S. and Tiongco, R. 1996. What has theology to do with development, peace and reconstruction? in The role of Christianity in development, peace, and reconstruction: Southern perspectives, edited by I.A. Phiri, K.R. Ross and J.L. Cox. Nairobi: All Africa Conference of Churches:10-29.

Williams, D.T. 1998. Theology in South Africa: The current situation. Themelios 23(3), June:27-41.

Wulff, D.M. 1997. Psychology of religion: Classic and contemporary. $2^{\text {nd }}$ edition. New York: Wiley. 